\title{
The tram-train system as an element of ecological public transport in the Polish agglomerations (part 2)
}

\section{Tram-train elementem proekologicznego systemu transportu zbiorowego $\mathrm{w}$ aglomeracjach w Polsce (cz. 2)}

The article presents an adverse impact of the transport in agglomerations on the environment and climate conditions. The sources and acceptable levels of environmental pollution and climate degradation are presented as well as contribution of the cars to this process, together with the actions undertaken with a view to reduce the emission. The trends in modernizing of the public transport systems are pointed out, inclusive of justification of the ecological tramtrain system implementation. The next part of the paper includes comparison of the features of the tram and passenger rail vehicles used for public transport in agglomerations. A brief outline of the actions initiated to implement the tram-train system in Poland is depicted. The final part of the article highlights the technical issues related to the difference between the tram and rail vehicle construction and equipment and discusses the scope of organizational and legal tasks necessary to undertake the practical measures. The Polish contractors potentially able to perform these tasks are indicated. In the last part a brief assessment of railway network suitability for implementation of the tram-train system was carried out on the example of the Poznan' agglomeration. An extensive bibliography makes an essential part of the paper.

The present article is a continuation of the earlier papers developed with participation of the author. Some of these problems have been only identified in the former papers and, therefore, they are discussed here more clearly, due to their importance to the topic of the tram-train system.

The present text is a continuation of the paper of the same title, published in the quarterly Pojazdy Szynowe nr 4/2019.

$W$ artykule przedstawiono negatywne oddzialywanie transportu zbiorowego $w$ aglomeracjach na stan środowiska i klimat. Opisano źródła i dopuszczalne poziomy zanieczyszczeń środowiska $i$ degradacji klimatu oraz udziat samochodów w tym procesie oraz podejmowane działania dla ograniczenia emisji. Przedstawiono uzasadnienie wdrażania ekologicznego systemu tram-train oraz tendencje unowocześniania systemów komunikacji zbiorowej. W dalszej części artykułu porównano cechy tramwaju i pasażerskich pojazdów kolejowych jako środków transportu zbiorowego $w$ aglomeracjach. W krótkim zarysie opisano działania, jakie zostaty podjęte dla wdrożenia systemu tram-train $w$ Polsce. W końcowej czéści artykutu odniesiono się do zagadnień technicznych zwiazanych z różnicami w zakresie budowy $i$ wyposażenia tramwajów i pojazdów kolejowych, a także omówiono zakres prac organizacyjno-prawnych, których podjęcie jest niezbędne dla rozpoczęcia działań praktycznych. Wskazano potencjalnych realizatorów tych dziatań na poziomie krajowym. W ostatniej części przeprowadzono, na przykładzie aglomeracji poznańskiej, krótka analize przydatności sieci kolejowej do wprowadzenia systemu tram-train. Istotna częścia artykułu jest obszerna lista bibliografii.

Niniejszy artykut jest kontynuacja wcześniejszych artykułów, których autor byt współautorem. $W$ poprzednich artykutach niektóre zagadnienia byty tylko zasygnalizowane, dlatego jednak $w$ zwiqzku z ich istotnym znaczeniem dla tematu systemu tram-train zostały omówione szerzej. Tekst jest kontynuacja artykulu pod tym samym tytutem, zamieszczonym w kwartalniku Pojazdy Szynowe nr 4/2019. 


\section{The action aimed at implementing the tram- train system in Poland}

First of all, it is worth recalling the beginning of implementation of the tram-train system in Europe, that was noted in Germany in the city of Karlsruhe. In 1992, took place the first service of the dual tram-train manufactured by Siemens. The Karlsruhe model is mainly based on the vehicle's ability to run on the lines of traditional $1435 \mathrm{~mm}$ two-rail track provided with two different supply voltages: $15 \mathrm{kV}-162 / 3 \mathrm{~Hz}$ for the railways and $750 \mathrm{~V}$ for the tram. The vehicles run on the city tracks in accordance with traditional tram traffic rules, while on the railway tracks in compliance with the rules applicable on Deutsche Bahn routes. The existing railway sections were used for purposes of the Karlsruhe solution. At present, 12 dual tram-train lines are operated in the city, within the distance of up to $70 \mathrm{~km}$ from the city centre, serving 190 stations.

Apart from Karlsruhe, the tram-train system is at present operative in five other German cities, i.e. in Saarbücken, Kassel, Chemnitz, Zwickau and Nordhausen. Moreover, it runs also in the Netherlands (The Hague), France (île-de-France), Spain (Alicante) and in the USA (New Jersey) [14, 20].

The problem of adverse impact of the road transport (mainly passenger cars and public transport buses) on the environment has been noticed also in Poland, particularly in large agglomerations. Already at the end of the last century this issue has arisen in many scientific and technical journals as well as at national and international conferences. This is indicated by the publication dates quoted at the end of the present paper.

In Poland, the tram-train projects are still in the consideration stage related only to several cities, such as Wrocław, Kraków, and Gdańsk. In 1998, the first attempts to drive the $105 \mathrm{~N}$ tram on the railway track have been performed. These tests were carried out on the railroad between the stations Kraków Główny Kraków Batowice - Kraków NowaHuta - Kraków Bieżanów, Kraków Bieżanów - Niepołomice, and Kraków Główny - Wieliczka. The design of the integrated rail transport system was aimed at the use of existing railway lines and sidings for both rail and tram traffic. The research run consisted in towing the $105 \mathrm{NT}$ test tram by a draisine. During the test run the tram's behavior was checked while passing the turnouts, inclusive of the scissors crossover and the switch point. Positive results enabled further, independent run tests at the speed of up to $60 \mathrm{~km} / \mathrm{h}$, that confirmed usefulness of the $105 \mathrm{~N}$ type standard design tram for running on the railroad.

The tests allowed to conclude the following:

- a standard tram is able to drive on a railroad;

- the main tram circuit should be adapted also to the $3 \mathrm{kV}$ supply voltage;

\section{Działania podjęte dla wdrożenia systemu tram- train w Polsce}

$\mathrm{Na}$ wstępie warto przypomnieć początek wdrażania systemu tram-train w Europie, który miał miejsce w Niemczech w miejscowości Karlsruhe. W 1992 roku odbył się pierwszy kurs tramwaju dwusystemowego wyprodukowanego przez firmę Siemens. Model Karlsruhe bazuje głównie na możliwości poruszania się pojazdu na liniach o dwóch różnych napięciach zasilania: $15 \mathrm{kV}-16^{2} /{ }_{3} \mathrm{~Hz}$ dla kolei i $750 \mathrm{~V}$ dla tramwaju i wykorzystuje także tradycyjne dwuszynowe torowisko o szerokości $1435 \mathrm{~mm}$. Po torach miejskich pojazdy poruszają się zgodnie z tradycyjnymi zasadami ruchu tramwajowego, natomiast na torach kolejowych zgodnie z zasadami obowiązującymi na szlakach Deutsche Bahn. W rozwiazzaniu z Karlsruhe wykorzystano istniejące już odcinki linii kolejowych. Obecnie w mieście funkcjonuje 12 linii tramwaju dwusystemowego w promieniu do $70 \mathrm{~km}$ od centrum miasta, obsługujących 190 stacji.

Aktualnie system tram-train poza Karlsruhe funkcjonuje jeszcze w pięciu innych miastach w Niemczech Saarbücken, Kassel, Chemnitz, Zwickau i Nordhausen, ale także w Holandii (Haga), Francji (Île-deFrance), Hiszpanii (Alicante) i w USA (New Jersey) $[14,20]$.

Również w Polsce zauważono problem negatywnego wpływu transportu samochodowego (głównie samochodów osobowych ciężarowych i autobusów komunikacji miejskiej), szczególnie w dużych aglomeracjach i już w końcu minionego wieku temat ten pojawił się na łamach wielu czasopism naukowotechnicznych i na konferencjach krajowych i międzynarodowych. Wskazują na to daty publikacji przytoczonych na końcu artykułu.

W Polsce przedsięwzięcie typu tram-train znajduje się nadal w fazie rozważań teoretycznych i dotyczy kilku tylko miast, takich jak Wrocław, Kraków, Gdańsk. W 1998 r. miała miejsce pierwsza próba jazdy tramwaju $105 \mathrm{~N}$ na torach kolejowych. Badania te zostały przeprowadzone na szlaku kolejowym pomiędzy następującymi stacjami: Kraków Główny - Kraków Batowice - Kraków Nowa Huta - Kraków Bieżanów, Kraków Bieżanów - Niepołomice, Kraków Główny Wieliczka. Istotą projektu zintegrowanego systemu transportu szynowego miało być wykorzystanie istniejących linii kolejowych $\mathrm{i}$ bocznic $\mathrm{z}$ dopuszczeniem na nich ruchu zarówno kolejowego jak i tramwajowego. Jady testowe odbyły się roboczym wagonem tramwajowym typu 105NT holowanym przez drezynę. Podczas jady testowej sprawdzono zachowanie tramwaju podczas przejazdu przez rozjazdy, w tym rozjazd krzyżowy i iglicę najazdową. Pozytywne rezultaty pozwoliły na kolejne, już samodzielne jazdy z prędkościami do $60 \mathrm{~km} / \mathrm{h}$, które potwierdziły, że tramwaj typu $105 \mathrm{~N}$ o standardowej konstrukcji może poruszać się po szlaku kolejowym. 
- it would be necessary to adapt the wheel profile to UIC standards, among others by installing a 135 $\mathrm{mm}$ tire, that in case of a tram would require clearing the rail track from the street pavement elements

Additionally, the problem of the tram turning back at the terminal loop must be solved. Therefore, only the shuttle trams should be used, unless a turning wye is built. What concerns the power supply, the links between the tram and rail overhead contact lines should be provided. $[6,7,21]$.

A seminar entitled "Integrated rail-tram systems" was held in November 1999. A number of the papers devoted to this topic were published in the monthly journal Technika Transportu Szynowego (TTS). The publication TTS No. 1-2 / 2000 including many papers related to the tram-train system application in Poland was dedicated to this topic. Particular attention was paid to implementation of this system in Krakow. A comparison of the operating cost components of the shuttle and conventional trams was presented, inclusive of the costs incurred by running the trams on the railway infrastructure. [9, 11, 23, 45, 46, 47].

Additionally, a preliminary forecast of the passenger flows in tram-train relations was estimated, and an example of daily transport demand for selected traffic directions was calculated. The current regulations related to rail and tram vehicles operation within the city were reviewed, with consideration of the instructions of the PKP Group, with regard to:

- instructions R1 for rail operation;

- E1 signaling instructions;

- guidelines related to construction of the WTBE10 traffic control facilities;

- instructions on professional qualification of the employees on PKP area.

The analysis leads to the following conclusions: assuming good running characteristics of the vehicles, particularly concerning the wheel-rail interaction, the operating costs of the tram-train vehicles related to the infrastructure and the fees for the use of railway or tram infrastructure, should be about $1.50 \div 1.80$ $\mathrm{PLN} /$ per one vehicle-km. The total operating costs (in case of two $105 \mathrm{~N}$ type wagons with a capacity of 160 200 passengers) should amount to 10 PLN/per one train-km (according to the prices of 1998).

The project of "Krakow Fast Tram-Train System" project, aimed at organizing and implementing the transport services being part of the Integrated Public Transport System, requires many investments integrating both networks, namely:

- modernization of selected elements of the rail and tram network, in particular launching the power supply networks;

- adjustment of the stops;

- implementation of traffic control and protection systems;
Wyciagnięte podczas tych przejazdów testowych wnioski były następujące:

- tramwaj standardowej konstrukcji może poruszać się po szlaku kolejowym

- konieczne jest dostosowanie obwodu głównego tramwaju do zasilania także napięciem $3 \mathrm{kV}$

- niezbędne byłoby dostosowanie profilu kół do standardów UIC, m. in. przez założenie obręczy $135 \mathrm{~mm}$, co w warunkach toru tramwajowego wymagałoby udrożnienia toku szynowego przez usunięcie elementów nawierzchni ulicy.

Do rozwiązania pozostałby jeszcze problem nawracania tramwaju na pętli końcowej, co wymagałoby stosowania tylko tramwajów dwukierunkowych lub budowy trójkąta torów do nawracania. W zakresie zasilania konieczne byłoby także zbudowanie łączników między trakcyjną siecią tramwajową i kolejową $[6,7$, 21].

W listopadzie 1999 r. miało miejsce seminarium pt. "Zintegrowane systemy kolejowo-tramwajowe", a na łamach miesięcznika Technika Transportu Szynowego (TTS) ukazało się szereg artykułów dotyczących tego tematu. Tematowi zastosowania systemu tram-train $\mathrm{w}$ Polsce został poświęcony numer miesięcznika TTS nr 1-2/2000, w którym zamieszczono artykuły dotyczące systemu tram-train. Szczególną uwagę zwrócono na realizację tego projektu w Krakowie. Przedstawiono analizę składników kosztów eksploatacyjnych tramwajów dwusystemowych w odniesieniu do tramwajów konwencjonalnych oraz przeanalizowano koszty za użytkowanie tramwajów na infrastrukturze kolejowej $[9,11,23,45,46,47]$.

Ponadto dokonano wstępnej prognozy potoków pasażerów w relacjach kolejowo-tramwajowych i obliczono przykładową dobowa prace przewozową dla wybranych kierunków ruchu pojazdów oraz dokonano przeglądu obowiązujących przepisów dotyczących eksploatacji pojazdów kolejowych i tramwajowych w obrębie miasta przy uwzględnieniu instrukcji grupy PKP dotyczących:

- instrukcji o prowadzeniu ruchu kolejowego R1

- instrukcji sygnalizacji E1

- wytycznych budowy urządzeń sterowania ruchem WTB-E10

- instrukcji o przygotowaniu zawodowym pracowników na PKP.

Wnioski z przeprowadzonych analiz sa następujace: przy założeniu dobrych właściwości biegowych pojazdów, zwłaszcza w odniesieniu do współpracy układu koło - szyna, koszty eksploatacyjne tramwajów dwusystemowych odniesione do infrastruktury oraz związane z nimi opłaty za użytkowanie infrastruktury kolejowej lub tramwajowej, powinny kształtować się na poziomie $1,5 \div 1,8 \mathrm{zl} / \mathrm{wozo} \cdot \mathrm{km}$, a całkowite koszty eksploatacyjne (odpowiadające dwóm wagonom typu $105 \mathrm{~N}$, o pojemności $160-200$ pasażerów) będą kształtowały się na poziomie $10 \mathrm{zt} /$ poc $\cdot \mathrm{km}$ (ceny z $1998 \mathrm{r}$.). 
- purchase of the rolling stock and preparation of the background required for its operation.

The tram-train system was proposed not only for Krakow. In 2007, at the INFRASZYN Scientific and Technical Conference, the concept of a tram-train system was also presented for Wrocław. The idea consisted in connecting the existing Poświętne and Kromera tram terminals with the railroad No. 292 on the section between the Wrocław Soltysowice and Wrocław stations. Moreover, a number of other analytic studies and expert opinions were provided at the Wrocław University of Technology, related to introduction of this system in the city, nevertheless, these ideas have not been implemented until to-day [27].

Further undertakings in the field of development of public rail transport in the Polish cities did not, however, cover the work aimed at introducing the tramtrain system.

For example, in Krakow, the envisioned tram system fully maintains the existing classic and fast tram network. Taking into account the standards to be achieved on the classic tram network, its forecasted development is limited to extending or connecting the existing sections or the network ends [28].

Similarly in Łódź, the development of public transport will be based on development of the connections implemented by the Łódź Agglomeration Railway and the trams, a larger number of which are at present purchased from the EU funds [29].

Under the public transport system offered at present for Wrocław, a tram rather than a bus is preferred. This is due to higher frequency of the courses, availability of many lines at a single stop, unchanging routes, better punctuality and regularity that result from separation of the tracks from the routes of other vehicles. It was ascertained that construction of underground tram or railway communication is technically and technologically feasible. Three subway lines have been primarily planned, that improve accessibility of the system cooperating with three transport means i.e. subway, tram and bus [30].

In the Upper Silesia industrial region a substantial modernization of the existing tram infrastructure is expected in the coming years. The company Tramwaje Śląskie S.A.(Silesian Trams Inc.) implements the program "Modernization of tram and trolleybus infrastructure in the Upper Silesian Agglomeration together with the supporting infrastructure". The program envisages, among others, purchase of 30 new low-floor trams and modernization of $75105 \mathrm{~N}$ ones. The tram-train system is not anticipated [31].

In Gdańsk the main emphasis related to development of public transport is placed on the tram transport.

Development of the tram communication network by 2025is expected mainly in the south-western parts of the area of Gdańsk, distinguished by growing population rate and, in consequence, higher transportation
Przedsięwzięcie "Dwusystemowy Krakowski Szybki Tramwaj", które ma zorganizować i realizować usługi przewozowe $w$ ramach Zintegrowanego Systemu Transportu Zbiorowego, wymaga wielu inwestycji, które będą integrować obie sieci, między innymi takich jak:

- modernizacja wybranych elementów sieci kolejowej i tramwajowej, szczególnie uruchomienia energetycznych sieci zasilających

- dostosowanie przystanków

- wdrożenie systemów sterowania i zabezpieczenia ruchu

- zakup taboru i przygotowanie zaplecza niezbędnego do jego funkcjonowania.

Propozycję wprowadzenia systemu tram-train przedstawiono nie tylko dla Krakowa. W 2007 roku na konferencji Naukowo-Technicznej „INFRASZYN” zaprezentowano koncepcję wprowadzenia tramwaju dwusystemowego także we Wrocławiu. Pomysł dotyczył połączenia istniejącej pętli tramwajowej Poświętne i Kromera, z linią kolejową nr 292 na odcinku pomiędzy stacjami Wrocław Sołtysowice i Wrocław. Ponadto na Politechnice Wrocławskiej wykonano szereg innych analiz i ekspertyz dotyczących wprowadzenia tego systemu w mieście, jednak pomysłów tych nie zrealizowano do dzisiaj [27].

Późniejsze działania w zakresie rozwoju zbiorowego transportu szynowego $\mathrm{w}$ polskich miastach nie uwzględniały jednak prac przy systemie tram-train.

Przykładowo w Krakowie planowany system tramwajowy zachowuje w całości istniejącą sieć tramwaju klasycznego i szybkiego. Z uwagi na standardy, jakie osiagane są na sieci tramwaju klasycznego, jego planowany rozwój ogranicza się do wydłużenia lub połączenia istniejących odcinków lub końcówek tej sieci [28].

Również w Łodzi rozwój komunikacji zbiorowej oparty będzie na rozwoju połączeń realizowanych przez Łódzką Kolej Aglomeracyjną oraz tramwaje, których większy zakup z funduszy unijnych jest obecnie realizowany [29].

W obecnie oferowanym systemie transportu zbiorowego dla Wrocławia, preferowany jest raczej tramwaj niż autobus, ze względu na większą częstotliwość kursowania, zebranie wielu linii na jednym przystan$\mathrm{ku}$, niezmienność tras, wyższy stopień punktualności i regularności, wynikający $\mathrm{z}$ wydzielania torowisk $\mathrm{z}$ ruchu innych pojazdów. Stwierdzono, że istnieją możliwości techniczne i technologiczne budowy odcinków podziemnej komunikacji tramwajowej lub kompletnej kolei podziemnej. Wstępnie wyznaczono trzy linie metra, które podnoszą poziom dostępności przy współdziałaniu systemu z trzema środkami przewozowymi: metro, tramwaj, autobus [30].

W przemysłowym rejonie Górnego Śląska przewiduje się w najbliższych latach gruntowną modernizację istniejącej infrastruktury tramwajowej. Spółka Tram- 
demand. The investment programme related to development of the tram routes in this area was divided into 6 stages[32].

The first relevant information on initial analysis related to implementation of the tram-train system in the Poznań agglomeration was presented during the 12th Scientific Conference "Railroads 2003" - 10.2003 [15, 36 and at the conference "Integrated urban rail transport system" - 04.2003 [24]. In the Poznan Agglomeration, that will be discussed hereinafter, the undertaken measures are limited to advancement of existing tram communication and further development of the Metropolitan Railway [22].

In Poznań itself, an extensive integration tram-train passenger transport is envisaged. This should be achieved, among others, by establishing convenient interchanges on both systems and a joint "tram-busrail" ticket. Four interchange nodes are considered to be the most important for the integration of both systems: Poznań Wschód, Poznań Główny, Franowo loop, Jan III Sobieski Station [33].

Among the disadvantages of the tram-train systems the transport capacity lower than that of the rail transport should be mentioned. This is caused by the tram rolling stock gauge of only $2200 \div 2650 \mathrm{~mm}$. Another serious problem may result from transferring the delays caused by city traffic to punctuality of the railway connections. Nevertheless, the use of tram tracks is much less expensive than extending the railway lines. In order to facilitate the launch of the work, the railway and tram regulations relating to approval of a tram on rail track must be unified.

At present, the work towards implementation of the tram-train system is not in progress in any larger city in Poland, despite the fact that such a solution enables to use the local rail lines more effectively, as the travelers can commute from their place of residence directly to the city centre and to return without changing to other communication means [18 ].

Activity of leading domestic manufacturers aimed at this goal can be observed on the example of the competitions announced by the National Centre for Research and Development (NCBR). Under the INNOTABOR Sector Programme of 2016, two projects related to the tram-train system have been submitted to the competition by the rolling stock manufacturers [3]:

- Developing a platform of a family of Polish innovative rail vehicles adaptable to urban conditions, ensuring alternative use of an internal combustion and/or electric engine, with running gear enabling adaptation to varying infrastructure.

- A tram-train vehicle adapted for use on tram tracks and on rail lines.

It may be expected that with the course of time the tram-train idea will reappear in the transport plans of Polish cities as an alternative to road and bus transport. waje Śląskie S.A. realizuje program „Modernizacja infrastruktury tramwajowej i trolejbusowej w Aglomeracji Górnośląskiej wraz z infrastrukturą towarzyszącą", w ramach którego przewidziany jest $\mathrm{m}$. in. zakup 30 nowych, niskopodłogowych tramwajów oraz modernizacja 75 tramwajów typu $105 \mathrm{~N}$. Nie przewiduje się zadań związanych z systemem tram-train [31].

Także w Gdańsku główny akcent rozwoju publicznego transportu zbiorowego kładzie się na transport tramwajowy. Przewiduje się, że rozwój sieci komunikacji tramwajowej do roku 2025 r. obejmie południowo-zachodnie części obszaru Gdańska charakteryzujące się rosnącym wskaźnikiem zaludnienia i w konsekwencji większym zapotrzebowaniem na transport. Program inwestycyjny rozbudowy tras tramwajowych w tym zakresie podzielono na 6 etapów [32].

Pierwsze istotne informacje dotyczące wstępnej analizy dotyczącej wdrożenia systemu tram-train $\mathrm{w}$ aglomeracji poznańskiej przedstawiono $\mathrm{w}$ trakcie XII Konferencji Naukowej "Drogi kolejowe 2003" $10.2003[15,36]$ oraz $\mathrm{w}$ trakcie konferencji "Zintegrowany system miejskiego transportu szynowego" 04.2003 [24]. W Aglomeracji Poznańskiej, która będzie przedmiotem rozważań w dalszej części artykułu, prowadzone działania ograniczają się do rozwoju istniejącej komunikacji tramwajowej i dalszym rozwoju Kolei Metropolitalnej [22].

W samym Poznaniu przewiduje się maksymalne zintegrowanie szynowego transportu pasażerskiego tramwajowego i kolejowego, m. in. poprzez stworzenie dogodnych węzłów przesiadkowych na obu systemów oraz wspólny bilet "tramwaj-autobus-kolej". Jako kluczowe dla integracji obu systemów wskazuje się cztery węzły: Dworzec Wschodni, Poznań Główny, pętlę Franowo, Dworzec Jana III Sobieskiego [33]. Do wad systemów kolejowo-tramwajowych należy zaliczyć mniejszą od kolei zdolność przewozową, ze względu na tramwajową skrajnię taboru, wynosząca tylko 2200? $2650 \mathrm{~mm}$. Poważnym problemem może być także przenoszenie opóźnień wynikających z ruchu w mieście na punktualność połączeń kolejowych. Wykorzystanie torowisk przez tramwaj jest jednak znacznie tańsze, niż przedłużanie linii kolejowych.

Dla ułatwienia uruchomienia prac wskazane i konieczne jest ujednolicenie przepisów kolejowych i tramwajowych $\mathrm{w}$ zakresie dopuszczenia tramwaju na torowiska kolejowe.

Prac dla wprowadzenia systemu tram-train nie prowadzi obecnie żadne duże miasto $\mathrm{w}$ Polsce, mimo że system tramwaju dwusystemowego umożliwia lepsze wykorzystanie lokalnych linii kolejowych, gdyż podróżni mogą dojeżdżać z miejsca zamieszkania bezpośrednio do centrum miasta i wracać bez konieczności przesiadki na inne środki komunikacji [18].

Można stwierdzić aktywność czołowych krajowych producentów w tym kierunku można zaobserwować śledząc konkursy ogłaszane przez Narodowe Centrum 
5. Technical and organizational-legal problems

5.1. Tram adaptation for running on railway infrastructure

Substantial differences in the construction and equipment of a tram as compared to EMU-type rail vehicles are as follows:

- different supply voltages in the overhead line;

- different contact force between the pantograph and the overhead line;

- different lighting, signage and communication systems;

- different traffic safety and control systems;

- different strength conditions of the EMU body construction and the tram;

- different tram and rail wheel profiles;

- different tram and rail gauges;

- different heights of railway and tram stop platforms (the door thresholds may be located on two levels);

- different wheel unit load limits;

- safe distance between the raised pantographs in case of their breaking [34].

One of the most important problems consists in safe wheel-rail interaction on all the track elements, such as crossing frogs and switches. The rail and tram wheelsets being at present in use are not suitable for running both on railway and tram tracks $[25,26]$.

In order to allow running of a single wheelset both on the rail and tram tracks two viable options are possible, provided the following conditions are met:

a) reconstruction of the railway tracks, including:

- elimination of all double slip switches (socalled English switches) and replacing them with two opposing switches;

- replacement of all switches with a "closed heart" type, as in these switches the check rails are unnecessary;

- elimination of all the track curves widening the track gauge;

b) reconstruction of tram vehicles and the following minor modifications of the railway track:

- the use of a wheel rim of changed dimension and shape;

- raising the lower contour of the tram kinematic gauge from the current height of $60 \mathrm{~mm}$ above the rail head to higher level so as to enable safe passage of the vehicle over the higher check rails.

Therefore, all the tram elements lowly suspended on the tram bogie or body, such as traction gear trains,

disc brakes, axle boxes, rakes, etc. should be redesigned.

The vehicle variant should be chosen based on economic analysis, with consideration of the costs to be incurred for implementation of a particular option, separately for each region in which the tram-train vehicle is to be operated.
Badań i Rozwoju NCBR. W Programie Sektorowym INNOTABOR z 2016 roku zostały zgłoszone do konkursu przez producentów taboru dwa projekty, które dotyczyły systemu tram-train [3]:

- Opracowania platformy rodziny polskich innowacyjnych pojazdów szynowych kolejowych adaptowalnych do warunków miejskich z możliwościa alternatywnego zastosowania silnika spalinowego i/lub elektrycznego z układem biegowym przystosowujacym się do zmiennej infrastruktury.

- Pojazd tramwajowo-kolejowy przystosowany do eksploatacji na torowiskach tramwajowych i na liniach kolejowych.

Można się spodziewać, że za jakiś czas idea tramwaju dwusystemowego powróci do planów transportowych Polskich miast, jako alternatywa dla transportu samochodowego i autobusowego.

\section{Zagadnienia techniczne i organizacyjno-prawne 5.1. Przystosowanie tramwaju do jazdy $w$ infra- strukturze kolejowej}

Podstawowe różnice w budowie i wyposażeniu tramwaju w stosunku do pojazdów kolejowych typu e.z.t. są następujące:

- różne napięcia zasilające w sieci napowietrznej

- inna siła docisku pantografu do sieci napowietrznej

- różne systemy oświetlenia, oznakowania, łączności

- różne systemy bezpieczeństwa i sterowania ruchem

- inne warunki wytrzymałościowe dla konstrukcji pudła e.z.t. i wagonu tramwajowego

- różne profile kół tramwajowych oraz kolejowych

- inne wymiary skrajni tramwajowej i kolejowej

- inna wysokość peronów kolejowych niż wysepek tramwajowych (progi drzwi mogą być na dwóch poziomach)

- różne dopuszczalne naciski jednostkowe koła na szynę

- bezpieczne, w przypadku wyłamania, odległości między podniesionymi pantografami [34].

Jednym $\mathrm{z}$ istotniejszych problemów jest bezpieczna współpraca układu koło-szyna na wszystkich elementach toru, takich jak krzyżownice i rozjazdy. Obecnie nie można wytypować spośród będących w eksploatacji zestawów kołowych, zarówno kolejowych jak i tramwajowych takich zestawów, które mogłyby bezproblemowo jeździć zarówno po torach kolejowych jak i tramwajowych $[25,26]$.

Istnieją dwa realne warianty realizacji przejazdu tego samego zestawu kołowego zarówno po torze kolejowym, jak i tramwajowym po spełnieniu warunków:

a) przebudowy torów kolejowych w tym:

- likwidację wszystkich krzyżownic rozwartokątnych (tzw. rozjazdów angielskich), zastępując je układem dwóch przeciwbieżnych zwrotnic 
An universal wheelset able to pass both a railroad and a tram track switch should be provided with the wheels of lateral dimensions shown in Fig. 1, with an additional layer of the material ensuring its rim profile to be identical to the present rim of the tram wheel.

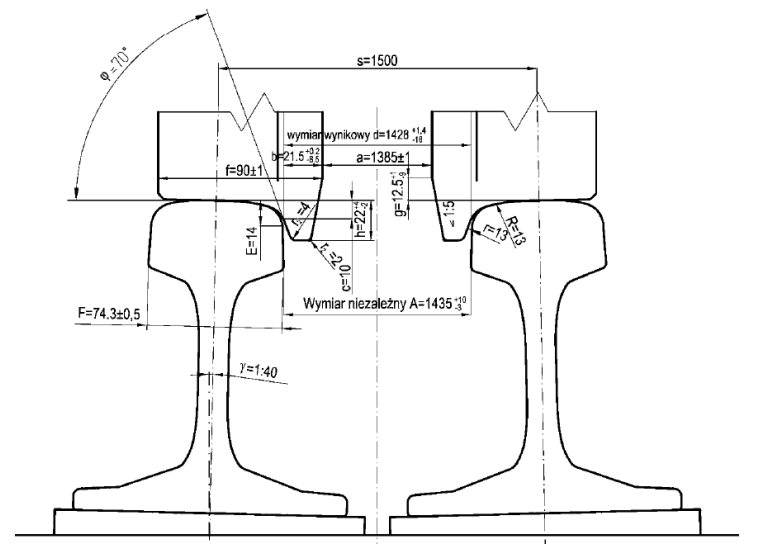

Fig. 1. A tram wheelset on a straight track built of the train rails [25]

Rys. 1. Tramwajowy zestaw kołowy na prostym torze zbudowanym z szyn kolejowych [25]

Many specialist publications contain the proposals of various configuration variants of the trams adapted to the railway tracks $[8,9,10,12,13,47]$.

\subsection{Necessary organizational measures and legisla- tive changes pertaining to the tram-train system}

The tram and rail transport are based on quite different regulations. In case of tram introduction to the railway lines the regulations related to both these areas must be adapted accordingly. This applies both to the provisions related to the tram construction and equipment, resulting in tram adaptation to specific requirements of the railway infrastructure, as well as to legal provisions governing operation of the trams on the rail tracks, inclusive, for example, of the rights of the tram drivers to operate a tram on rail tracks.

The documents authorizing the train driver to drive a railway vehicle include the train driver's license and train driver's certificate [44]. The trainings and exams necessary to obtain them are subjected to legal regulations [19]. The scope of knowledge and skills covered by the training and examination for the train driving license is specified by the decree, covering also a detailed training program [35]. As a result, in order to run a tram on the rail tracks a proper authorization is required, determined by the provisions to be laid down in the future.

The rights of tram drivers may be limited, as they authorize to drive on strictly defined railroads, therefore, it is felt that the training process might be simplified too. The necessary legislative actions have already been signaled in several publications $[13,14]$.

The earlier presented list of European cities operating the tram-train systems gives evidence that the problem
- wymianę wszystkich zwrotnic na typ z "zamykanymi sercami", gdyż takie zwrotnice nie potrzebują kierownic

- wyeliminowanie wszystkich łuków torów poszerzenia prześwitu toru,

b) przebudowy pojazdów tramwajowych i małych przeróbek torów kolejowych następująco:

a)zastosowanie wieńca koła o zmienionym wymiarze i kształcie

b)podniesienie dolnego konturu skrajni kinematycznej tramwaju z obowiązującej obecnie wysokości $60 \mathrm{~mm}$ nad główką szyny na wyższy, aby pojazd mógł bezpiecznie przejechać nad wyższymi kierownicami zwrotnic kolejowych.

W związku z tym musiałyby zostać przekonstruowane wszystkie elementy tramwaju, zawieszane nisko na wózku lub podwoziu, takie jak: zębate przekładnie trakcyjne, hamulce tarczowe, korpusy maźnic, odgarniacze itp.

Wybór wariantu powinien być dokonany w oparciu o analizę ekonomiczną, uwzględniającą koszty jakie należałoby ponieść dla realizacji poszczególnego wariantu, oddzielnie dla każdego rejonu, po którym byłaby przewidziana jazda pojazdu typu tram-train.

Uniwersalny zestaw kołowy, który byłby zdolny do przejazdu zarówno przez zwrotnicę kolejową, jak i przez tramwajowa, musiałby mieć koła, których wymiary poprzeczne byłyby takie, jak przedstawiono na rys. $1 \mathrm{z}$ uwzględnieniem dodatkowej warstwy materiału, by jego obrzeże byłoby identyczne $\mathrm{z}$ obecnym obrzeżem koła tramwajowego.

Wśród publikacji specjalistów można znaleźć szereg propozycji dotyczących różnych wariantów konfiguracji tramwajów przystosowanych do jazdy na torach kolejowych [8, 9, 10, 12, 13, 47].

\subsection{Niezbędne działania organizacyjne oraz zmiany legislacji dotyczące systemu tram-train oraz ich realizatorzy}

Transport wykorzystujący tramwaje opiera się na zdecydowanie innych przepisach niż komunikacja kolejowa. Wprowadzenie tramwaju na linie kolejowe wymaga dostosowania obowiązujących przepisów z obu tych obszarów. Dotyczy to zarówno przepisów związanych z konstrukcją i wyposażeniem tramwajów, dostosowujących tramwaj do specyfiki infrastruktury kolejowej, jak i regulacji prawnych dotyczących eksploatacji tramwaju na torach PKP, w tym przykładowo uprawnienia motorniczych do prowadzenia tramwaju na torach kolejowych.

Dokumentami uprawniającymi maszynistę do prowadzenia pojazdu kolejowego są licencja maszynisty oraz świadectwo maszynisty [44]. Prowadzenie szkoleń i egzaminów niezbędnych do ich uzyskania jest działalnością regulowaną przepisami [19]. Zakres wiedzy i umiejętności objętych szkoleniem i egzaminem na licencję maszynisty określają zapisy rozporządzenia, zawierające 
has been successfully solved and these systems operate there without technical and formal problems. For example, in Chemnitz in Germany, the approval procedure has been so defined, that the first tests are carried out in accordance with the railway requirements, the opinion of authorized bodies is worked out and the vehicle is approved for running on the railroad. Afterwards, the additional tests are carried out according to the requirements of the tram regulations. Their approval results in authorization and closure of the procedure $[1,2,4,5]$.

\section{Appropriateness of launching the tram-train system on the example of the Poznań agglomera- tion}

This section presents some aspects framing the possibility and legitimacy of implementing a tram-train system as a support of the public transport on the example of the Poznań agglomeration. A similar review is also possible with regard to other Polish agglomerations.

Table 1 presents selected demographic data related to the Poznan agglomeration (on the right) and broken down into particular municipalities of the agglomeration (on the left).

Wyszczególnienie $\ldots=$ Specification, Powierzchnia $\mathrm{w}$ $\mathrm{km}^{2} \ldots=$ Area in $\mathrm{km}^{2}$, Ludność ... Population, Ludność na ...= Population per $1 \mathrm{~km}^{2}$, Przyrost naturalny ...= Rate of natural increase per 1000 inhabitants, Województwo ...= The Wielkopolska Province, Aglomeracja ...= Poznań agglomeration

\begin{tabular}{|c|c|c|c|c|}
\hline WYSZCZEGÓLNIENIE & $\begin{array}{l}\text { Powierz- } \\
\text { chnia } \\
\text { w km² }\end{array}$ & Ludność & $\begin{array}{l}\text { Ludnośc } \\
\text { na } 1 \mathrm{~km}^{2}\end{array}$ & $\begin{array}{c}\text { Przyrost } \\
\text { natura Iny } \\
\text { na } 1000 \\
\text { ludności }\end{array}$ \\
\hline Województwo wielkopolskie & 29827 & 3493969 & 117 & 1,0 \\
\hline Aglomeracja poznańska & 3082 & 1042659 & 338 & 2,7 \\
\hline Buk & 91 & 12562 & 139 & 5,6 \\
\hline Czerwonak & 82 & 27518 & 334 & 2,4 \\
\hline Dopiewo & 108 & 26759 & 248 & 8,6 \\
\hline Kleszczewo & 74 & 8440 & 113 & 11,2 \\
\hline Komornikj & 66 & 29378 & 442 & 13,2 \\
\hline Kostrzyn & 155 & 18261 & 118 & 2,0 \\
\hline Kórnik & 186 & 28304 & 152 & 9,3 \\
\hline Lubon & 14 & 31783 & 2353 & 2,7 \\
\hline Mosina & 171 & 33053 & 193 & 4,6 \\
\hline Murowana Goslina & 172 & 16864 & 98 & 3,3 \\
\hline Obomikj & 340 & 34157 & 100 & 3,0 \\
\hline Pobiedziska & 190 & 19551 & 103 & 0,5 \\
\hline Poznań & 262 & 536438 & 2048 & 0,7 \\
\hline Puszczykowo & 16 & 9698 & 592 & $-4,7$ \\
\hline Rokjetrica & 79 & 17770 & 224 & 7,3 \\
\hline Skoki & 198 & 9659 & 49 & 5,7 \\
\hline Stęszew & 175 & 15032 & 86 & 0,2 \\
\hline Suchy Las & 116 & 17599 & 152 & 5,1 \\
\hline Swarzędz & 102 & 50667 & 498 & 6,9 \\
\hline Szamotuly & 176 & 30047 & 171 & 0,6 \\
\hline Srem & 206 & 42050 & 204 & 2,7 \\
\hline Tarnowo Podgórne & 102 & 27069 & 266 & 6,2 \\
\hline
\end{tabular}

także szczegółowy program szkolenia [35]. Wynika z tego, że prowadzenie tramwaju na trasach kolejowych będzie wymagało uprawnień, które zostaną określone dopiero w przepisach redagowanych w przyszłości.

Uprawnienia motorniczych $\mathrm{z}$ racji prowadzenia pojazdów na ściśle określonych trasach kolejowych mogą być ograniczone, zatem wydaje się, że i proces szkolenia może być uproszczony. Niezbędne działania legislacyjne zostały już zasygnalizowane $\mathrm{w}$ kilku publikacjach $[13,14]$.

$\mathrm{Z}$ przedstawionej wcześniej listy miast europejskich eksploatujących system tram-train wynika, że problem ten został skutecznie rozwiązany i systemy te funkcjonują tam bez problemów technicznych i formalnych. Przykładowo Chemnitz w Niemczech dopracowano procedurę dopuszczenia $\mathrm{w}$ ten sposób, że najpierw wykonywane są badania wg wymagań kolejowych, opracowywana jest opinia uprawnionych organów i pojazd uzyskuje dopuszczenie kolejowe, a następnie wykonywane są badania uzupełniające wg wymagań przepisów dla tramwaju, ich zaopiniowanie i wydanie zezwolenia oraz zamknięcie procedury $[1$, $2,4,5]$.

\section{Zasadność uruchomienia systemu tram-train na przykładzie aglomeracji poznańskiej}

W niniejszym rozdziale przedstawiono niektóre aspekty związane z możliwością i zasadnością wdrożenia rozwiązania tram-train, jako uzupełnienie systemu komunikacji zbiorowej na przykładzie aglomeracji poznańskiej. Podobny przegląd jest możliwy także w odniesieniu do innych aglomeracji w Polsce.

$\mathrm{W}$ tablicy 1 przedstawiono wybrane dane demograficzne o aglomeracji poznańskiej (po prawej) oraz w rozbiciu na gminy tej aglomeracji (po lewej)

\section{Table 1.Demographic data about the municipalities of the Poznań agglomeration [17]}

Tablica 1.Dane demograficzne o gminach aglomeracji poznańskiej [17]

\begin{tabular}{|l|r|r|r}
\hline \multicolumn{1}{|c|}{ Wybrane dane statystyczne } & $\mathbf{2 0 1 6}$ & $\mathbf{2 0 1 7}$ & $\mathbf{2 0 1 8}$ \\
\hline Powierzchnia w km ${ }^{2}$ & 3082 & 3082 & 3082 \\
\hline Ludność & 1029021 & 1035715 & 1042659 \\
\hline Ludność na $1 \mathrm{~km}^{2}$ & 334 & 336 & 338 \\
\hline Kobiety na $100 \mathrm{męźczyzn}^{2}$ & 110 & 110 & 110 \\
\hline Ludność w wieku: & & & \\
\hline przedprodukcyjnym & 193726 & 198367 & 202425 \\
\hline produkcyjnym & 631905 & 627296 & 624437 \\
\hline poprodukcyjnym & 203390 & 210052 & 215797 \\
\hline
\end{tabular}

Wybrane dane ... = Selected statistical data, Powierzchnia $\ldots=$ Area in $\mathrm{km}^{2}$, ludność ...= Population, Ludność na ...= Population per $1 \mathrm{~km}^{2}$, Kobiety na ... Number of women per 100 men, Ludność w ... = Population in:, przedprodukcyjnym ..= pre-working age, produkcyjnym ..= working age, poprodukcyjnym...$=$ post-working age 
For purposes of a simplified analysis it is advisable to refer to the plans of the Poznan Metropolitan Railway (PMR). The plan of the network is shown in Fig. 2 below

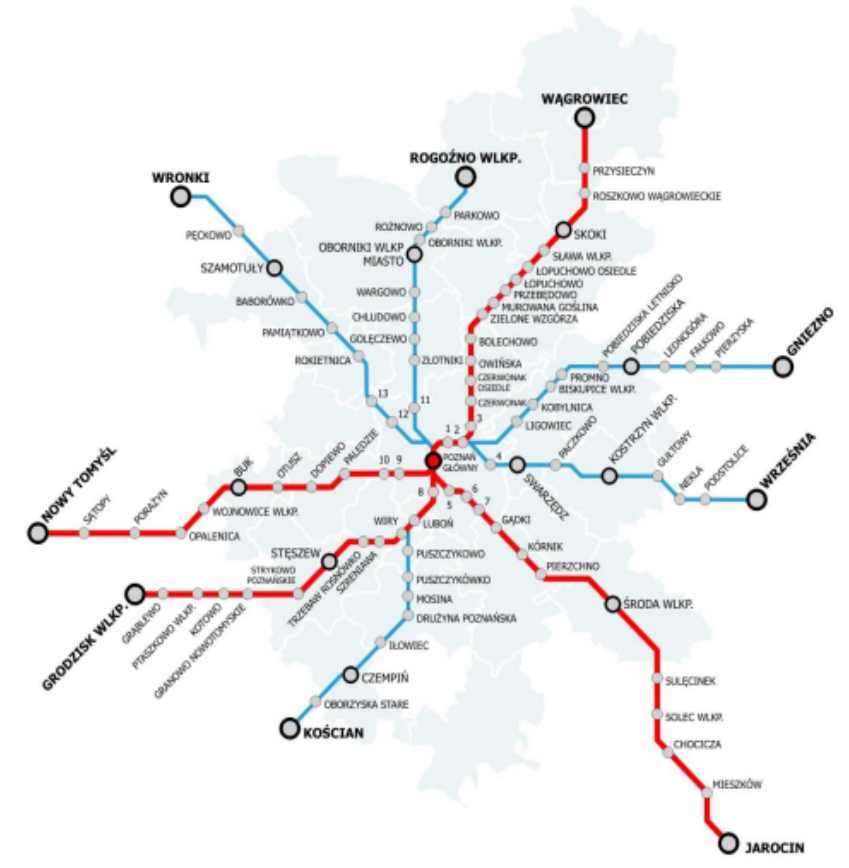

Fig. 2. Diagram of the rail connections in the future PMR area [16]

Description: red - 1st stage 2018, blue - 2nd stage 2019-2021

Przystanki - the stopsi: 1 - P-ń Garbary, 2 - P-ń Wschód, 3 - P-ń Karolin, 4 - P-ń Antoninek, 5 - P-ń Dębina, 6 - P-ń Starotęka, 7 P-ń Krzesiny, 8 - P-ń Dębiec, 9 - P-ń Górczyn, 10 - P-ń Junikowo, 11 - P-ń Strzeszyn, 12 - P-ń Wola, 13 - Kiekrz

Rys. 2. Schemat połączeń kolejowych na przyszłym obszarze działania PKM [16]

Opis: kolor czerwony - I etap 2018, kolor niebieski - II etap 20192021

Przystanki: 1 - P-ń Garbary, 2 - P-ń Wschód, 3 - P-ń Karolin, 4 $P-n ́ n$ Antoninek, 5 - P-ń Dębina, 6 - P-ń Starołęka, 7 - P-ń Krzesiny, 8 - P-ń Dębiec, 9 - P-ń Górczyn, 10 - P-ń Junikowo, 11 - P-ń Strzeszyn, 12 - P-ń Wola, 13 - Kiekrz

Fig. 2 and Table 1 give evidence of the following relevant information:

- $29.8 \%$ of the Wielkopolska Province population live in the Poznan agglomeration;

- the area of the Poznań agglomeration represents approximately $10.3 \%$ of the province area;

- The Poznań Metropolitan Railway supports most of the Poznań agglomeration localities, except for Kleszczewo, Komorniki, Suchy Las, Śrem and Tarnowo Podgórne.
Celowe dla prowadzonej uproszczonej analizy jest odniesienie się do planów Poznańskiej Kolei Metropolitalnej. Plan tej sieci przedstawiono na poniższym rys. 2.

$\mathrm{Z}$ rys. 2 i z tabl. 1 wynikają istotne informacje:

- w aglomeracji poznańskiej zamieszkuje 29,8\% ludności woj. wielkopolskiego

- powierzchnia aglomeracji poznańskiej stanowi około $10,3 \%$ powierzchni województwa

- Poznańska Kolej Metropolitalna obsługuje większość miejscowości aglomeracji poznańskiej, za wyjątkiem Kleszczewa, Komornik, Suchego Lasu, Śremu i Tarnowa Podgórnego.

Table 2. The PMR parameters

Tablica 2. Parametry PKM

\begin{tabular}{|l|r|r|r|}
\hline \multicolumn{1}{|c|}{ Kierunek } & $\begin{array}{c}\text { Odległość } \\
\text { [km] }\end{array}$ & $\begin{array}{c}\text { Liczbastan- } \\
\text { ków }\end{array}$ & $\begin{array}{c}\text { Odległ. śr. } \\
{[\mathrm{km}]}\end{array}$ \\
\hline Wągrowiec & 57 & 17 & 3,4 \\
\hline Skoki & 40 & 13 & 3,1 \\
\hline Gniezno & 50 & 12 & 4,2 \\
\hline Września & 49 & 10 & 4,9 \\
\hline Jarocin & 67 & 12 & 5,6 \\
\hline Środa Wlkp & 34 & 7 & 4,9 \\
\hline Kościan & 42 & 10 & 4,2 \\
\hline Czempiń & 32 & 8 & 4,0 \\
\hline Grodzisk Wlkp & 51 & 12 & 4,3 \\
\hline Nowy Tomyśl & 57 & 11 & 5,2 \\
\hline Wronki & 51 & 8 & 6,4 \\
\hline Rogoźno Wlkp & 45 & 10 & 4,5 \\
\hline Oborniki Miasto & 29 & 6 & 4,8 \\
\hline Oborniki Wlkp & 31 & 7 & 4,4 \\
\hline
\end{tabular}

Ponadto ze schematu połączeń kolejowych wynikają średnie odległości międzyprzystankowe ujęte w tablicy 2.

Największa średnia odległość międzyprzystankowa 6,4 km występuje na trasie Poznań Gł. - Wronki, a najmniejsza 3,1 km na trasie Poznań Gł. - Skoki. Na podstawie wcześniej przedstawionych obliczeń (w rozdz. $3.4 \mathrm{w}$ cz. 1 artykułu) można szacować zużycie dla podobnych warunków jazdy. Uzasadniony jest szacunek, że zużycie energii na trasach z odległościami $3 \div 4 \mathrm{~km}$ (np. kierunki na Skoki, Wagrowiec, Czempiń, Kościan i Gniezno) przez tramwaj będzie wynosiło ok. $100 \mathrm{kWh}$, a przez e.z.t. ok. dwukrotnie więcej.

Moreover, the diagram of the rail connections allows to calculate the average inter-stop distances shown in Table 2.

The largest average inter-stop distance amounts to $6.4 \mathrm{~km}$ on the route Poznan G1. - Wronki, while the shortest is $3.1 \mathrm{~km}$ on the route Poznan G1. - Skoki. The previously presented calculation (chapter 3.4, part 1 of the article) allows to estimate the power consumption under similar running conditions. Appraisal of power consumption of a tram equal to $100 \mathrm{kWh}$ at the $3 \div 4 \mathrm{~km}$ distances (e.g. towards Skoki, Wagrowiec, Czempiń, Kościan and Gniezno), and about twice as large in case of EMU is justified. 
This applies to the cases of average filling of the railway cars, which is expected in case of a reasonable timetable. For example, 43 trains (inclusive of 17 long-distance ones) run on the Poznań - Gniezno route during the working day, while 24 connections were launched on the route to Wagrowiec.

These data indicate that assumption of the railway car filling not exceeding the average one is reasonable.

The total number of inhabitants in the localities located on the considered route Poznań - Gniezno (excluding Poznań) amounts about to 110 thousand. Such a number justifies the development of prospective assumptions of the public transport on this line, at least partly based on the tram-train system. Figures 3 and 4 below show, for example, two maps presenting the mutual positions of the tram terminal loops and railway lines in the Poznan agglomeration.

The connections of other tram loops located near the railroad should also be considered:

- the tram loop at Sobieskiego Housing Estate - the connection to the 351 railway line to Szamotuly, the access track length about $100 \mathrm{~m}$;

- the Ogrody tram loop - the connection to the railway line 354 to Oborniki Wlkp. (it would be necessary to enter the track on the embankment, instead it would be reasonable rather to enter at the West Railway Station), the access track of about $600 \mathrm{~m}$;

- the Starołęka tram loop - the connection to the railway line No. 272 to Środa Wlkp.), the access track of about $50 \mathrm{~m}$;

- the Górczyn tram loop - the connection to the railway line No. 3 to Buk, the access track of approx. $50 \mathrm{~m}$.

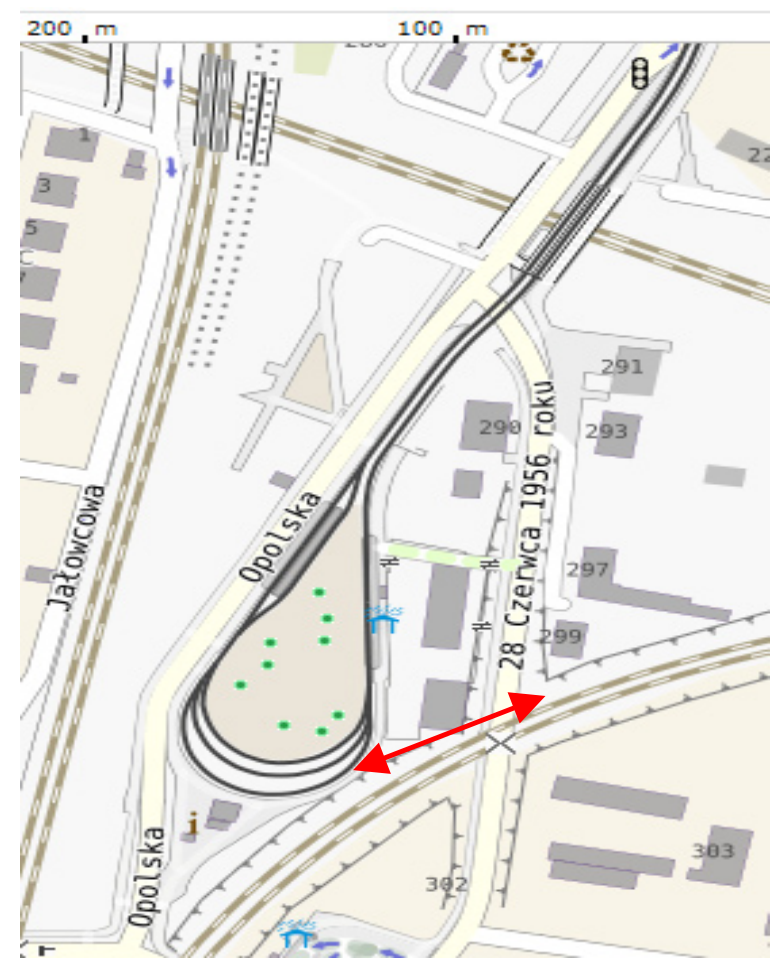

Dotyczy to przypadku przeciętnego zapełnienia pojazdów, bo takiego należy się spodziewać przy racjonalnym rozkładzie jazdy. Przykładowo na trasie Poznań Gniezno kursują w ciagu dnia roboczego 43 pociagi (w tym 17 dalekobieżnych), a na trasie do Wagrowca uruchomiono 24 połączenia.

Dane te w wskazują, że zasadne jest założenie nie większego niż przeciętne zapełnienie pojazdów.

Łączna liczba mieszkańców w miejscowościach na analizowanej trasie Poznań - Gniezno (z wyłączeniem Poznania) wynosi ok. 110 tys. Ta liczba uzasadnia opracowanie założeń perspektywicznej komunikacji zbiorowej na tej linii opartej co najmniej częściowo o system tram-train. Na poniższych rysunkach 3 i 4 przedstawiono przykładowo dwie mapki przedstawiających wzajemne usytuowanie pętli tramwajowych i linii kolejowych w aglomeracji poznańskiej.

- pętla Os. Sobieskiego. Połączenie do linii kolejowej 351 do Szamotuł, łącznik ok. $100 \mathrm{~m}$

- pętla Ogrody. Połączenie do linii kolejowej 354 do Obornik Wlkp. (z pętli konieczny byłby wjazd na torowiska na nasypie, zasadny byłby wjazd przy Dworcu Zach.), łącznik ok. $600 \mathrm{~m}$

- pętla Starołęka. Połączenie do linii kolejowej nr 272 do Środy Wlkp, łącznik ok. $50 \mathrm{~m}$

- pętla Górczyn. Połączenie do linii kolejowej nr 3 do Buku, łącznik ok. $50 \mathrm{~m}$.

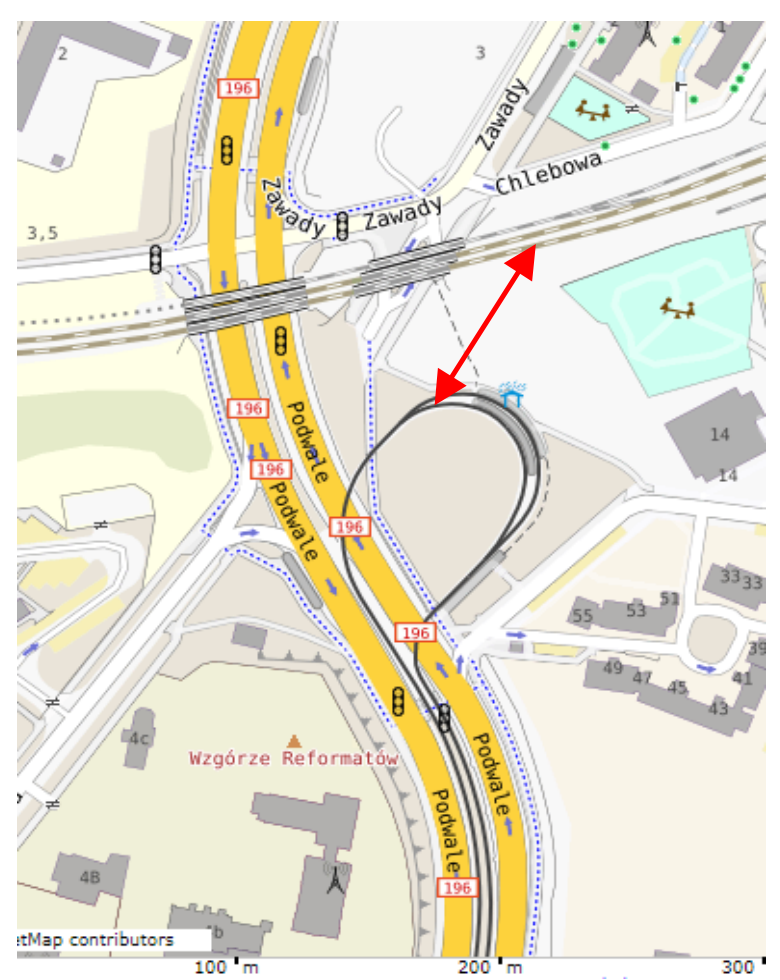

Fig. 4. The Zawady tram loop. Connection to the railway lines No. 356 to Skoki and Wagrowiec and No. 353 to Gniezno

Rys. 4. Pętla Zawady. Połączenie do linii kolejowych nr 356 do Skoków i Wagrowca i nr 353 do Gniezna

Fig. 3. The Dębiec tram loop. Connection to the railway lines No. 271 to Czempiń and Kościan and No. 357 to Grodzisk Wlkp Rys. 3. Pętla Dębiec. Połączenie do linii kolejowych nr 271 do Czempinia i Kościana i nr 357 Grodziska Wlkp. 
The circumstances influencing the legitimacy of developing the tram-train lines in specific directions should be taken into account. These circumstances include, among others:

- traffic density (the railway line category, e.g. 0category in case of the railway line 3 towards Września);

- length of the required tram access track. Such a link could be built without the overhead line, the tram should be then powered e.g. by a highefficiency energy accumulator;

- average distance between the stops of the railway line to which the access track leads;

- the density of land development, especially at the housing areas;

- vertical terrain profile (in the example of Fig. 4, the levels of the tram and rail lines differ considerably from each other).

Construction of the access track between the tram and rail networks should be subjected to detailed analysis. Among others, the track type and its optimum location should be taken into account. In practice two variants are feasible, i.e. in the city centre or in the vicinity of the tram loops.

The access location in the centre is rather contraindicated, due to high-density housing, organizational difficulties related to connecting with the railway network. On the other hand, the access location in suburbia (e.g. tram terminal loop) enables the use of the existing tram stops, thus improving the transport offer in both directions.

The access track may be built in two variants: with or without the overhead contact line. In the second case the tram will run by own momentum or the use a socalled powerpack or high-efficiency energy storage will be necessary. The choice should depend on the length of the access track.

Analysis of population size of the European cities where the tram-train system was launched indicates that they are implemented both in very large cities (Ile de France - Paris region: 2, 2 million population, Vienna: 1.84 million), as well as in the smaller ones (Gmunden: 13,000, Nordhausen: 42,000). The other 15 cities having such a system have several hundred thousand inhabitants.

In the event of positive results of the analyzes, the tram-train system should be implemented on all the routes leading from Poznan to the agglomeration localities possessing already the rail transport. On the other hand, in the case of several other ones (Kleszczewo, Komorniki, Suchy Las, Śrem and Tarnowo Podgórne) the validity of establishing a new track section dedicated to the system should be additionally considered. Values of the length of these additional tracks oscillates from several hundred meters (Suchy Las) to about $6 \mathrm{~km}$ (Kleszczewo).
Należy mieć na uwadze okoliczności, które mają wpływ na uznanie zasadności rozwijania linii tramtrain w określonych kierunkach. Do tych okoliczności należą $\mathrm{m}$. in.:

- zagęszczenie ruchu (kategoria linii kolejowej, np. kategoria 0 dla linii kolejowe nr 3 w kierunku Wrześni)

- długość wymaganego łącznika linii tramwajowej, przy czym należałoby uwzględnić, że łącznik taki mógłby być zbudowany bez sieci trakcyjne, a w czasie przejazdu po nim tramwaj zasilany byłby np. z wysokowydajnego zasobnika energii

- średnia odległość międzyprzystankowa linii kolejowej, do której miałby być prowadzony łącznik

- gęstość zabudowy terenu, zwłaszcza zabudowy mieszkalnej

- ukształtowanie pionowe terenu (na przykładzie sytuacji na rys. 4 lokalizacja pozioma linii tramwajowej i kolejowej znacznie się różni).

Elementem szczegółowej analizy powinna być także sprawa budowy łączników między siecią tramwajową a kolejową. Powinna uwzględnić $m$. in. typ łącznika oraz optymalną lokalizację. Możliwe są praktycznie dwa warianty, w centrum miasta lub w pobliżu pętli tramwajowych.

Przeciwwskazaniem lokalizacji w centrum jest gęsta zabudowa, trudności organizacyjne związane $\mathrm{z}$ wjazdem na sieć kolejowa, a wskazaniem na lokalizację na obrzeżach miasta (np. pętla tramwajowa) jest możliwość wykorzystania dotychczasowych przystanków tramwajowych, co poprawia ofertę przewozową w obu kierunkach przemieszczania się.

Łącznik może być wykonany w dwóch wariantach: z siecią trakcyjną oraz bez niej. W przypadku łącznika bez sieci tramwaj będzie przemieszczał się wybiegiem lub korzystał z tzw. powerpacka lub wysoko wydajnego zasobnika energii. Wybrany wariant będzie zależał od długości łącznika.

$\mathrm{Z}$ analizy wielkości populacji miast europejskich, w których uruchomiono system tram-train, wynika że systemy te zostały wdrożone zarówno $\mathrm{w}$ miastach bardzo dużych (Ile de France - region paryski: 2, 2 mln ludności, Wiedeń: 1,84 mln), jak również mniejszych (Gmunden: 13 tys., Nordhausen: 42 tys.). Pozostałe 15 miast $\mathrm{z}$ takim systemem liczy po kilkaset tysięcy mieszkańców.

W przypadku uzyskania pozytywnych wyników odpowiednich analiz, system tram-train należy wdrażać na wszystkie trasy prowadzące z Poznania do miejscowości aglomeracyjnych już objętych komunikacją kolejowa, a w przypadku kilku (Kleszczewo, Komorniki, Suchy Lasu, Srem i Tarnowo Podgórne) należy rozważyć zasadność dobudowania odcinka dedykowanego temu systemowi. Długości tych dodatkowych torowisk to od kilkuset metrów (Suchy Las) do ok. 6 km (Kleszczewo). Dobrym przykładem zapewnienia dobrej komunikacji zbiorowej we wszystkich kierunkach może być układ sieci torów, na których wdrożo- 
The layout of the tram-train system implemented in Chemnitz and described in part one of the article is a positive example of public transport operating in all the directions.

The conclusions on the service costs of the current transport offer provided by rail vehicles for the agglomeration inhabitants are as follows:

- purchases of the rolling stock designed for serving such the routes will be less expensive in the case of a tram-train system, even taking into account a tram adapted to run on the railway network, as e.g. in the Chemnitz network area (see chapter 3.3, part 1 of the article);

- the services of average stream of passengers performed with rail vehicles require, at least on some of the routes mentioned above, almost twice as much power as comparable tram services. The volumes of the passenger streams and frequency of the trains between the localities of the Poznan agglomeration are presented in [3, 22]. Nevertheless, the time elapsed since the compilation of these data should be taken into account.

- smaller mass of a tram, especially that of its unsprung parts, results in less labor-consuming and less expensive inspection and repair works on the tracks;

- environmental nuisance resulting, among others, from the noise level and vibrations transmitted to the environment is smaller in the case of tram operation.

Predominant share of electric power cost in the operating expenses should be taken into account. The example percentage data for a locomotive over a 15 -year service life is shown in Fig. 5. In case of other rail vehicles these data are similar. The power cost accounts for around $70 \%$ of all the operating expenses, moreover, a significant growth of the energy prices should be expected in the coming years.

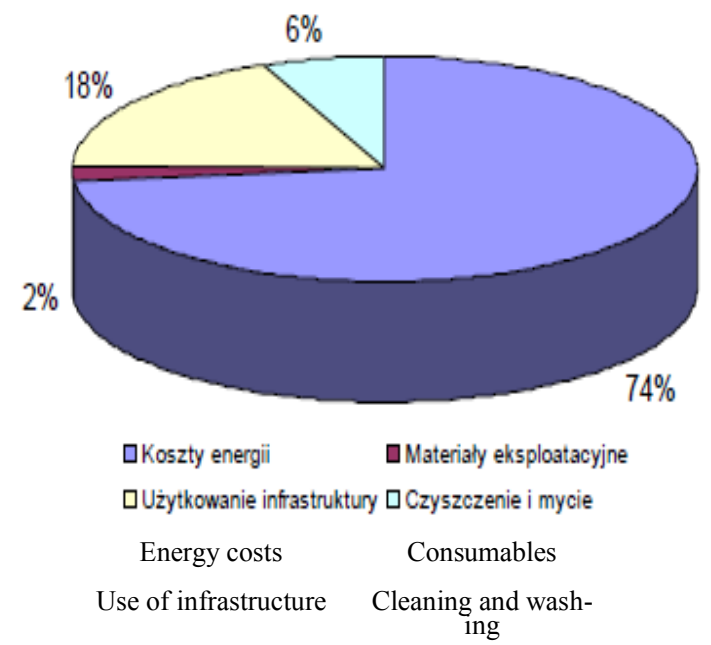

no system tram-train w Chemnitz, opisany w części pierwszej artykułu.

Wnioski dotyczące kosztów obsługi w odniesieniu do aktualnej oferty przewozowej pojazdami kolejowymi dla mieszkańców aglomeracji są następujące:

- zakupy taboru do obsługi takich tras będą mniej kosztowne w przypadku wdrażania systemu tramtrain, nawet tramwaju przystosowanego do jazdy po sieci kolejowej, jak to zrobiono np. dla obszaru sieci w Chemnitz (patrz rozdz. $3.3 \mathrm{w}$ cz. 1 artyku$\mathrm{hu})$

- obsługa przeciętnego potoku pasażerów pojazdami kolejowymi, co najmniej na części przedstawionych wyżej tras, wymaga praktycznie dwukrotnie większej energii niż porównywalne przewozy tramwajami. Wielkości takich potoków pasażerów i częstość pociągów między miejscowościami aglomeracji poznańskiej przedstawiono $\mathrm{w}[3,22]$, jednak należy mieć na uwadze czas, jaki upłynął od chwili opracowania tych danych.

- z uwagi na mniejsze masy tramwaju, zwłaszcza nieodsprężynowane, prace przeglądowo-naprawcze torowisk będą mniej pracochłonne i mniej kosztowne

- uciążliwość dla środowiska wynikająca m. in. z poziomu hałasu i drgań przenoszonych do otoczenia jest mniejsza w przypadku eksploatacji tramwaju.

Należy mieć na uwadze dominujący udział kosztów energii elektrycznej w kosztach eksploatacji. Dane procentowe, przykładowo dla lokomotywy w 15 letnim okresie eksploatacji, przedstawiono na rys. 5. Dla innych pojazdów szynowych te dane są porównywalne. Koszt energii stanowi ok. $70 \%$ wszystkich kosztów eksploatacji, a należy przewidywać istotny wzrost cen energii w kolejnych latach.

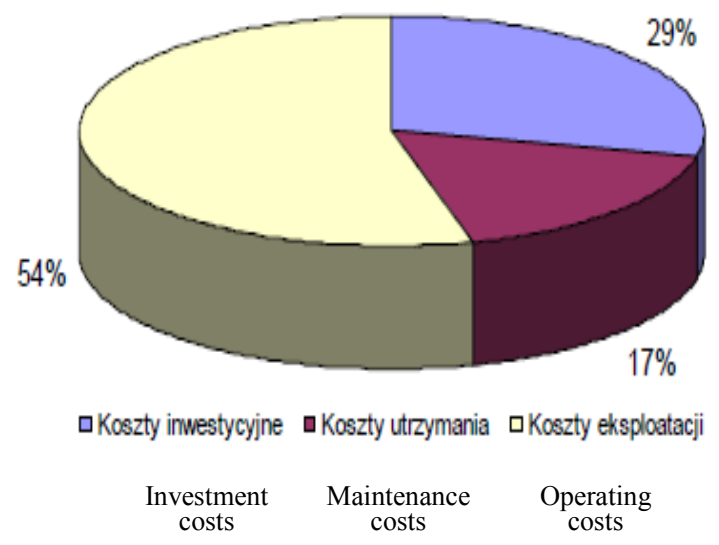

Fig. 5. The share of operating costs of a locomotive [43]

Rys. 5. Udział kosztów związanych z eksploatacją lokomotywy [43] 
Operation of the tram-train system exceeds the areas of the cities, therefore, the documents defining the development strategies of larger provinces of Poland should also be taken into account.

In the strategy of Warmia-Mazury province there is notation about put in motion, instead of liquidated non profitable for PKP railway lines, on the WarmiaMazury area alternative means of transport type railway trams [42]. The development strategies others province include only some general statements instead of any implementation plans, or at least analysis initiation. The plans formulated in these provinces are limited to the following statements:

- Pomerania Province: "Ensuring efficient transport connections with the economic centres of Poland and Europe, integration of the public transport system with a view to improve the internal cohesion of the province and mobility of its population (also in the urban scale), inclusive of the road and rail access to the areas distinguished by the lowest accessibility in the region" [ 40].

- DolnyŚlassk Province: "Establishment of an integrated transport system in the Wrockaw Metropolitan Area, consisting mainly on development of the rail transport and integrated public transport systems in other agglomerations based on lowemission urban transport, inclusive of the rail transport" [39].

- Małopolska Province: "The comprehensive transport development in the region shall consist in establishing further integrated interchanges, offering opportunities for integration of many transport systems. At the same time, the interchanges shall enable safe and convenient connections, both within the public, individual and public transport systems. Such a solution provides opportunities for comfortable waiting for the interchanges, ensuring current passenger information "[38].

- Wielkopolska Province: "An important factor supporting the development of the economy of Wielkopolska converts itself to provision of efficient connections facilitating the people mobility, access to the labor markets, public facilities, as well as to improving movement of the people from poorly accessible transport areas. Taking this into account, the collective transport plays a key role, with railway transport being of the highest importance. The key activities under this package consist in implementation of the transport model, including joint adjustment of the bus and rail

transport and integration of the rail transport

with urban transport". [41]

The government document that sets out the state's development strategy until 2030 includes no plans of tram-train system implementation. It contains only a short statement that "Improving the transport access to the labor markets and public facilities, as well as promoting mobility of inhabitants of the areas distin-
Funkcjonowanie systemu tram-train wykracza poza obszary miast, zatem należy się także odnieść do dokumentów zawierających strategie rozwojowe większych pod względem liczby ludności województw w Polsce.

W strategii województwa warmińsko-mazurskiego znalazł się zapis o uruchomieniu, w miejsce likwidowanych, nierentownych dla PKP linii kolejowych na Warmii i Mazurach, alternatywnych środków transportu typu tramwaje kolejowe [42]. W opracowanych strategiach rozwoju pozostałych województw, poza ogólnymi stwierdzeniami, nie znalazły się plany wdrożenia, nawet te dotyczące rozpoczęcia analiz. Plany tych województw ograniczają się do następujących stwierdzeń:

- województwo pomorskie: "Zapewnienie sprawnych powiazań transportowych z centrami gospodarczymi Polski i Europy, integracja systemu transportu zbiorowego dla zwiększenia spójności wewnętrznej województwa i mobilności mieszkańców (także $w$ wymiarze miejskim), w tym poprawa dostepności drogowej i kolejowej obszarów o najniższej dostępności w regionie" [40]

- województwo dolnośląskie: "Budowa zintegrowanego systemu transportu we Wrocławskim Obszarze Metropolitalnym glównie $w$ oparciu o rozwój systemu transportu szynowego oraz zintegrowanych systemów transportu zbiorowego na terenach pozostatych aglomeracji $w$ oparciu o niskoemisyjny transport miejski, w tym szynowy" [39]

- województwo małopolskie: "Dopetnieniem kompleksowego rozwoju transportu $w$ regionie będzie dalsza rozbudowa zintegrowanych węzłów przesiadkowych, które będa oferować możliwości integracji wielu systemów transportu. Węzty jednocześnie umożliwia bezpieczne $i$ wygodne przesiadki, zarówno $w$ ramach systemu publicznego transportu zbiorowego jak $i$ pomiędzy transportem indywidualnym $i$ transportem publicznym, stworzq możliwości komfortowego oczekiwania na połqczenia, zapewniajac bieżqca informacje pasażerska" [38]

- województwo wielkopolskie: "Istotnym czynnikiem wspierajacym rozwój gospodarki Wielkopolski jest zapewnienie sprawnych połaczeń ułatwiajacych przemieszczanie się ludzi, dostęp do rynków pracy, obiektów użyteczności publicznej, jak i zwiększajacych mobilność mieszkańców z obszarów słabo dostęnych transportowo. W tym zakresie szczególna role odgrywa transport zbiorowy, $w$ tym kolejowy. Kluczowymi działaniami w ramach tego pakietu będq: realizacja modelu transportowego obejmujacego wspólne organizowanie przewozów autobusowych $i$ kolejowych, integrowanie przewozów kolejowych $z$ transportem miejskim" [41]

W rządowym dokumencie określającym strategie rozwoju państwa do 2030 r. nie ujęto planów wdrażania systemów tram-train. Zawarto w nim tylko lako- 
guished by poor transport availability is of particular importance. The public transport, inclusive of the rail one, plays an important role in this respect." [37].

Thus, the idea of the tram-train system remains at the stage of the articles published in scientific and technical journals.

The final conclusion to be drawn from this concise and simplified analysis indicates that prior to launching the project of passenger rail systems development in the agglomeration areas, the benefits resulting from the system should be taken into account and carefully analyzed, as was done in other Western European cities.

Possible connection of the existing tram lines with railway tracks should be considered, taking into account circumstances such as the distance between these infrastructure networks and availability of the land designed for possible investment. In any case, both with regard to each direction of the connections from Poznań chosen as an example for the presented analysis, and with regard to other agglomerations in Poland, a detailed analysis of rationality of the tramtrain system implementation to the existing infrastructure should be carried out.

\section{The measures aimed at implementing the tram- train in Poland}

The launch of the tram-train systems implementation in Poland, e.g. in the form of a sectoral national program, is purposeful for the following reasons:

a) the use of the railway network in the agglomeration became common in tens of the cities, not only European ones;

b) feasibility and validity of the project implementation are confirmed by the information included in many publications. The analyzes related to this subject pertain to several cities in Poland;

c) the primary benefit will consist in reduction of the environmental pollution emitted by individual transport as well as the energy saving resulting from introduction of modern, innovative trams, equipped with the drive of the highest energy efficiency.

The program should be divided into two main stages:

A. Preparation of formal and legal basis of the projects:

- The advance measures aimed at interesting the carriers (the tram operators) and consistent steps to obtain a consent of the railway infrastructure owner to include the infrastructure into the modern public transport system in the agglomeration;

- the agreement of the directions of changes, with the UTK and DTD, allowing to adapt the tram to running on railway tracks.

B. launching technological projects promoting series production of an innovative tram, covering the following tasks: niczne stwierdzenie, że "Szczególne znaczenie ma poprawa dostęności transportowej do rynków pracy, obiektów użyteczności publicznej, jak i zwiększanie mobilności mieszkańców w obszarach stabo dostępnych transportowo. W tym zakresie wazna role odgrywa publiczny transport zbiorowy, $w$ tym transport kolejowy" [37].

Temat systemu tram-train pozostał zatem nadal na etapie artykułów w czasopismach naukowotechnicznych.

Końcowy wniosek z tej krótkiej, uproszczonej analizy wskazuje, że przed uruchomieniem przedsięwzięcia rozwijania pasażerskich systemów kolejowych na obszarach aglomeracji, należy wziąć pod uwagę i dokładnie przeanalizować korzyści z zastosowania systemu tram-train, jak to zrobiono $\mathrm{w}$ innych miastach Zachodniej Europy.

Należy wziać pod uwage możliwości połączenia istniejących linii tramwajowych $\mathrm{z}$ torami kolejowymi, biorąc pod uwage takie okoliczności jak odległość między tymi infrastrukturami oraz dostępność terenów pod ewentualną inwestycję. W każdym przypadku, zarówno w odniesieniu do każdego kierunku połączeń z Poznania, który został wybrany jako przykład do przedstawionej analizy, jak i w odniesieniu do innych miast aglomeracyjnych w Polsce, należy przeprowadzić szczegółową analizę racjonalności wprowadzenia systemu tram-train do istniejącej infrastruktury kolejowej.

\section{Dzialania w celu wdrożenia systemów tram-train w Polsce}

Uruchomienia przedsięwzięcia wdrożenia w Polsce systemów tram-train, np. w formie sektorowego programu krajowego, jest celowe $\mathrm{z}$ następujących powodów:

a) wykorzystanie sieci kolejowej na terenie aglomeracji stało się powszechną praktyką w kilkudziesięciu już miastach, nie tylko europejskich

b) realność i zasadność realizacji przedsięwzięcia potwierdzają informacje $\mathrm{w}$ wielu publikacjach. Analizy na ten temat dotyczą kilku miast w Polsce

c) podstawową korzyścią będzie ograniczenie zanieczyszczania środowiska przez środki transportu indywidualnego oraz oszczędność energii w wyniku wprowadzenia do tego systemu nowoczesnych, innowacyjnych tramwajów z napędami o najwyższej sprawności energetycznej.

Program powinien zostać podzielony na dwa główne etapy:

A: przygotowanie podstaw formalnych i legislacyjnych dla projektów:

-wyprzedzające działania dla wytworzenia zainteresowania przewoźników (tramwaje) oraz konsekwentne kroki dla wyrażenie zgody właściciela infrastruktury kolejowej na włączenie infrastruktury do nowoczesnego 
- analysis of the state of technical legislation (the laws, regulations, standards, industry regulations) and selection of new acts, the changes and supplements in force, inclusive the ones related to authorization to drive such trams;

- analysis of the configuration, feasibility and legitimacy of additional use of the railway network in the Polish agglomerations;

- identification of legal status of already adopted solutions, on the example of a selected European city;

- agreeing the principles of the track sharing by PKP PLK, traffic organization, training of the tram drivers;

- development of technological solutions and construction documentation of the tram adapted to new operating modes;

- design of a double voltage drive system (600 $\mathrm{V} / 3 \mathrm{kV}$ );

- laboratory and field tests of the drive;

- construction of a demonstration drive to be used in the tram after positive results of the tests;

- construction of a demonstration tram.

Several contribute to designating the Lukasiewicz Research Network - Institute of Rail Vehicles TABOR as the coordinating unit in the field of the technical projects:

- it is a sole unit in Poland authorized, at the same time, to operate in the field of approving railway vehicles (in cooperation with the Office of Rail Transport) and trams (in cooperation with the Transport Technical Supervision);

- it was the initiator and performer of the organizational works for an innovative rolling stock, leading to launching the INNOTABOR Sector Program;

- it is a unit listed in the field of science as a partner in a dozen or so project cards submitted to the INNOTABOR program.

Effective cooperation of several state units will be necessary:

a) a competent Ministry (on the consultations on the scope of the changes in legal status);

b) UTK and TDT (in order to promote and formulate the legal regulations favorable for development of modern solutions at the frontier of rail and tram areas [14]);

c) PKP PLK;

as well as local units and manufacturers (for example):

d) MPK Poznań;

e) Poznan University of Technology - Faculty of Civil Engineering and Transport; systemu transportu zbiorowego na terenie aglomeracji

-Uzgodnienie z UTK i DTD kierunków zmian dostosowujących tramwaj do jazdy po torach kolejowych

B: uruchomienie projektów technicznych wspierających seryjną budowę innowacyjnego tramwaju, obejmujących następujące zadania:

-analiza stanu legislacji technicznej (ustawy, rozporządzenia, normy, przepisy branżowe) $\mathrm{i}$ wytypowanie aktów nowych oraz zmian i uzupełnień $\mathrm{w}$ obowiązujących $\mathrm{w}$ tym dotyczące uprawnień do prowadzenia takich tramwajów

-analiza konfiguracji, możliwości i zasadności dodatkowego wykorzystania sieci kolejowej na terenach aglomeracji w Polsce

-rozpoznanie stanu prawnego rozwiązań na przykładzie wybranego miasta europejskiego

-uzgodnienie zasady udostępniania torów przez PKP PLK, organizacja ruchu, szkolenie motorniczych

-opracowanie rozwiązań technicznych i dokumentacji konstrukcyjnej dla tramwaju dostosowanego do nowych trybów eksploatacji

- projekt dwunapięciowego układu napędowego $(600 \mathrm{~V} / 3 \mathrm{kV})$

- badania laboratoryjne i poligonowe napędu

- budowa demonstratora napędu do zabudowy na tramwaju po badaniach $\mathrm{z}$ pozytywnym wynikiem

-budowa egzemplarza tramwaju (demonstratora).

Koordynującą jednostką w zakresie projektów technicznych może być, z kilku powodów, Sieć

Badawcza Łukasiewicz - Instytut Pojazdów Szynowych TABOR:

- jest jedyną w Polsce instytucją uprawnioną równocześnie do działalności w zakresie dopuszczeń pojazdów kolejowych (we współpracy z Urzędem Transportu Kolejowego) oraz tramwajów (we współpracy z Transportowym Dozorem Technicznym)

- był inicjatorem i wykonawcą prac organizacyjnych na rzecz innowacyjnego taboru szynowego sfinalizowanego uruchomieniem Programu Sektorowego INNOTABOR

- jest jednostką wymienioną jako partner z obszaru nauki w kilkunastu kartach projektów zgłoszonych do programu INNOTABOR.

Konieczna będzie efektywna współpraca kilku jedno-

a) właściwe Ministerstwo (w sprawie konsultacji zakresu zmian stanu prawnego)

b) UTK i TDT (w promowaniu i tworzeniu regulacji prawnych dla rozwoju nowoczesnych rozwiązań dla styku obszarów kolejowo-tramwajowych [14]) 
f) FPS Poznań, NEWAG, PESA (or other manufacturer interested in the topic specified in the Research Agenda of the INNOTABOR program [3]).

It would be advisable to organize a meeting of interested parties, e.g. at the ministry, with a presentation being an introduction to the discussions and subsequent arrangements.

\section{Summary}

In order to solve the problem of the tram-train system implementation supporting the public transport a wide range of work- and time-consuming activities, partly discussed in chapter 7 , should be undertaken.

The operators interested in the venture should use, first of all, the knowledge on the solutions already implemented in several European agglomerations. This is the question of technical topics related to construction of the trams adapted to railway tracks, the regulations governing the traffic on the railway lines serving both rail and tram traffic, as well as the train drivers' training.

The next stage of the undertaking at the national level must include the cooperation with the state entities responsible for transport carried out by rail vehicles.

The decision to introduce the tram-train system should result from extensive, many sided consultations, studies and analyzes undertaken by the authorities of the cities and surrounding counties. All the relevant factors should be taken into account, inclusive of the size of the passenger flows on the considered routes, the distances between the central city and the satellite towns, the reserves in access to the railway line, distribution of the existing stops/train stations, comparison of the costs of current communication served by the railway carriers with future expenses in case of introduction of the tram-train system.

\section{Bibliography / Bibliografia}

c) PKP PLK

oraz jednostek lokalnych i producentów (przykładowo):

d) MPK Poznań

e) Politechnika Poznańska - Wydział Inżynierii Lądowej i Transportu

f) FPS Poznań, NEWAG, PESA (lub inny producent zainteresowany tematem ujętym $\mathrm{w}$ Agendzie Badawczej programu INNOTABOR [3]).

Celowe byłoby zorganizowanie narady zainteresowanych, np. w ministerstwie, z prezentacją wprowadzającą do dyskusji i późniejszych uzgodnień.

\section{Podsumowanie}

Rozwiązanie problemu wdrożenia systemu tram-train, jako wspomagającego publiczną komunikację zbiorową, wymaga podjęcia szeregu praco- i czasochłonnych działań, częściowo omówionych w rozdz. 7.

W pierwszej kolejności zainteresowane podmioty powinny wykorzystać wiedzę na temat rozwiązań, jakie wdrożono w kilkunastu już aglomeracjach europejskich. Dotyczy to wiedzy na tematy techniczne dotyczące budowy tramwajów przystosowanych do jazdy po torach kolejowych, przepisów prowadzenia ruchu na liniach kolejowych obsługujących zarówno ruch kolejowy jak i tramwajowy i szkolenia motorniczych.

Działania w kolejnym etapie na poziomie krajowym muszą być prowadzone we współpracy jednostek państwowych odpowiedzialnych za transport realizowany pojazdami szynowymi.

Decyzja o wprowadzeniu systemu tram-train powinna wynikać z szerokich, wielowątkowych konsultacji, studiów i analiz przeprowadzonych przez władze miast i otaczających je powiatów Pod uwagę powinny zostać wzięte wszystkie istotne czynniki, takie jak m. in.: wielkość potoków pasażerów na analizowanych trasach, odległości między miastem centralnym a miejscowościami satelickimi, rezerwy w dostępności do linii kolejowej, gęstość rozmieszczenia istniejących przystanków/stacji kolejowych, porównanie kosztów istniejącej obsługi komunikacji przez przewoźników kolejowych z przyszłymi kosztami po wprowadzeniu systemu tram-train.

[1] 2002-2018. Das Chemnitzer model. Folder firmy Verkehrsverbund Mittelsachsen GmbH

[2] Ab Ende 2020 mit der "Straßenbahn" von Chemnitz nach Aue. https://www.mdr.de/sachsen/chemnitz/chemnitzstollberg/vms-ausbau-chemnitzer-modell-aue-100.html

[3] Agenda Badawcza Programu Sektorowego INNOTABOR. Innowacyjny tabor szynowy do przewozów pasażerskich, towarowych i specjalnego przeznaczenia. Komunikat Internetowy Narodowego Centrum Badań i Rozwoju. Warszawa 15.07.2016: https://www.ncbr.gov.pl/programy/fundusze-europejskie/poir/nabory-zakonczone/

[4] Beim M.: Uwarunkowania prawne tramwaju dwusystemowego w Niemczech.

[5] Chemnitz tram-train passenger traffic doubles. https://www.railjournal.com/passenger/light-rail/chemnitz-tramtrain-passenger-traffic-doubles/

[6] Czauderna T.: Próbne jazdy wagonu 105NT na szlakach kolejowych. Świat Kolei 1998

[7] Czauderna T.: Próbne jazdy wagonu tramwajowego 105NT po torach kolejowych. TTS nr 7-8/1998

[8] Czeczuła W.: Warunki techniczne jakim powinna odpowiadać infrastruktura kolejowa i tramwajowa ze względu na ruch pojazdów dwusystemowych. TTS 1-2/2000 
[9] Czyczuła W., Jeżewicz J.: Wstępna analiza kosztów eksploatacyjnych tramwajów dwusystemowych TTS 1-2/2000

[10] Czyczuła W., Raczyński J.: Zintegrowane systemy kolejowo--tramwajowe. TTS nr 7-8/2001

[11] Czyczuła W.: Koncepcja zintegrowanego systemu transportu zbiorowego dla Krakowa - dlaczego tramwaj dwusystemowy? TTS nr 1-2/2000

[12] Dabrowski J.: Jaki w polskich warunkach powinien być tramwaj dwusystemowy. TTS 1-2/2014

[13] Dąbrowski J.: Techniczno-prawny aspekt użytkowania tramwaju na polskich torach tramwajowych i kolejowych. TTS 11/2018

[14] Durzyński Z., Pachołek M, Cichy R.: The premises for adapting tram for driving on various types of track in an urban agglomeration. Pojazdy Szynowe 4/2017

[15] http://www.dk2003.pg.gda.pl/konferencja-dk2003.pdf

[16] https://kolej2e-wielkopolskie.com.pl/wp-content/uploads/2017/12/slajd-5.pdf

[17] https://poznan.stat.gov.pl/vademecum/vademecum_wielkopolskie/portret_obszaru_metropolitalnego/aglomeracja_ poznanska.pdf

[18] https://www.transport-publiczny.pl/wiadomosci/tramwaj-i-kolej-na-jednym-torze-byc-moze-59455.html

[19] https://www.utk.gov.pl/pl/aktualnosci/15346,Szkolenie-maszynistow-oraz-pracownikow-na-pozostalychstanowiskach-kolejowych.html? search $=17017294172$

[20] Jakiel J., Oleszczuk Ł.: Rozwiqzania transportowe w aglomeracjach. http://web.archive.org/web/20140203090248/http://www.ibspan.waw.pl/stzm/do-pobrania/Pasmo\%20 Grodziskie\%20-\%20rozwiazania\%20transportowe.pdf

[21] Komunikat internetowy: https://pojazdy.moontech.pl/tramwaj-105n-na-torach-kolejowych/

[22] Koncepcja zintegrowanego transportu publicznego w oparciu o linie poznańskiego węzła kolejowego. Streszczenie kierownicze. WYG Consulting Sp. z o.o. Warszawa 2014

[23] Kraśkiewicz C., Oleksiewicz W.: Tramwaj dwusystemowy - moda czy trend rozwojowy aglomeracyjnego transportu szynowego? Logistyka 4/2015

[24] Krych A., Rychlewski J.: Rozwiqzania tramperowe w aglomeracji poznańskiej - idea, studia i problemy aplikacji. Materiały konferencji "Zintegrowany system miejskiego transportu szynowego". Wrocław, 24-25.04.2003

[25] Lang R., Nowak R.: Uwarunkowania dla jazdy tego samego zestawu kołowego po torze kolejowym i tramwajowym (1). Pojazdy Szynowe nr 1/2006

[26] Lang R., Nowak R.: Uwarunkowania dla jazdy tego samego zestawu kołowego po torze kolejowym i tramwajowym (2). Pojazdy Szynowe $n r$ 3/2006

[27] Makuch J.: Propozycja miejskiej linii tramwaju dwusystemowego dla Wrocławia. X Konferencja NaukowoTechniczna. "INFRASZYN". Zakopane 26-28.04.2017

[28] Plan zrównoważonego rozwoju publicznego transportu zbiorowego dla gminy Kraków $i$ gmin sqsiadujacych, $z$ którymi gmina Kraków zawarła porozumienie w zakresie organizacji publicznego transportu zbiorowego. Uchwała Rada Miasta Krakowa Nr LXXX/1220/13 z 28.08. 2013 r.

[29] Plan zrównoważonego rozwoju publicznego transportu zbiorowego dla Województwa Łódzkiego do roku 2020 z perspektywa do roku 2030. Uchwała XVII/178/15 Sejmiku Województwa Lódzkiego z 26.10.2015 r.

[30] Plan zrównoważonego rozwoju publicznego transportu zbiorowego dla Wrocławia na lata 2016 - 2022. Uchwała Nr XXXIV/713/16 Rady Miejskiej Wroctawia z 22.12.2016 r.

[31] Plan zrównoważonego rozwoju publicznego transportu zbiorowego dla obszaru komunikacyjnego zwiazku komunalnego górnoślaskiego okręgu przemystowego na lata 2013 - 2020. Komunikacyjny Zwiazek Komunalny GOP w Katowicach. Katowice, luty 2013 r.

[32] Plan zrównoważonego rozwoju publicznego transportu zbiorowego dla miasta Gdańska na lata 2014-2030. Gdańsk, styczeń $2014 \mathrm{r}$.

[33] Plan zrównoważonego rozwoju publicznego transportu zbiorowego dla miasta Poznania na lata 2014 - 2025. Biuro Inżynierii Transportu. Poznań. 2014

[34] Rozporzqdzenie Komisji (UE) nr 1301/2014 z dnia 18 listopada 2014 r. w sprawie technicznych specyfikacji interoperacyjności podsystemu ,Energia” systemu kolei w Unii

[35] Rozporzqdzenie Ministra Infrastruktury i Rozwoju z dnia 10 lutego 2014 r. w sprawie licencji maszynisty

[36] Rychlewski J.: Potencjat transportowy sieci kolejowej aglomeracji poznańskiej. XII Konferencja Naukowa "Drogi Kolejowe 2003". Gdańsk-Sobieszewo, 15-17.10.2003. http://www.dk2003.pg.gda.pl/konferencja-dk2003.pdf

[37] Strategia na rzecz Odpowiedzialnego Rozwoju do roku 2020 (z perspektywq do 2030 r.). Warszawa. 2017

[38] Strategia Rozwoju Województwa „Małopolska 2030”. Załacznik nr 1 do Uchwały nr 1612 /19 Zarzqdu Województwa Małopolskiego

[39] Strategia Rozwoju Województwa Dolnoślaskiego 2020. Urzq̨ Marszałkowski Województwa Dolnoślaskiego.

[40] Strategia Rozwoju Województwa Pomorskiego 2020. Załacznik nr 1 do Uchwaty nr 458/XXII/12 Sejmiku Województwa Pomorskiego. Gdańsk 2012

[41] Strategia rozwoju Województwa Wielkopolskiego do 2030 roku. Zarzqd Województwa Wlkp. Poznań, 2020

[42] Strategia Rozwoju Społeczno - Gospodarczego Województwa Warmińsko - Mazurskiego do roku 2020. Olsztyn, 2005

[43] Tułecki A., Szkoda M.: Koszt cyklu trwałości LCC jako model decyzyjny modernizacji pojazdów szynowych. Materiaty XVII Konferencji Pojazdy Szynowe, Kazimierz Dolny, 2006

[44] Ustawa o transporcie kolejowym. Dz. U. RP 2019 poz. 710 
[45] Walther G.: Zintegrowane systemy kolejowo-tramwajowe w Europie - stan obecny i perspektywy rozwoju TTS 12/2000

[46] Wańkowicz W.: Zagadnienia formalnoprawne, a dwusystemowy Krakowski Szybki Tramwaj. TTS nr 1-2/2000

[47] Wieczorek J.: Problemy eksploatacyjno-ruchowe zwiqzane z wprowadzeniem pojazdów dwusystemowych na sieć PKP TTS nr 1-2/2000 